\title{
Anthropometric and somatotype characteristics of undergraduate students of the National University of Science and Technology, Zimbabwe
}

\begin{abstract}
Objective: The present study aimed at evaluating anthropometric and somatotype characteristics of male and female part-time university students in the department of sports science and coaching.

Methods: 20 students were randomly selected for the investigation. The International Society for the Advancement of Kinanthropometry (ISAK 2011) standardised procedures were used to measure anthropometric variables. Measurements included body mass, stretch stature, 8 skinfolds, 5 girths and 2 bone breadths. The body composition variables calculated were body mass index (BMI), waist-to-hip ratio (WHR), percentage body fat (\%BF), fat mass (FM), fat-free mass (FFM), fat mass index (FMI) and fat free mass index (FFMI). The Health and Carter method was applied to calculate subjects' somatotype.

Results: The participants' mean age was $38 \pm 12$ years, height $1.68 \pm 7.48 \mathrm{~m}$ body mass $71.47 \pm 13.23 \mathrm{~kg}$, height $1.68 \pm 7.48 \mathrm{~m}$, sum of eight skinfolds $116.24 \pm 52.53 \mathrm{~mm}$, body mass index (BMI) $25.07 \pm 3.18$, body fat (BF) of $1.05 \pm 0.14 \%$, waist-to-hip ratio (WHR) $0.81 \pm 0.09$, fat mass (FM), was $1.37 \pm 6.35 \mathrm{~kg}$, fat-free mass (FFM) $57.73 \pm 9.97$ $\mathrm{kg}$, fat-mass index (FMI) $4.81 \pm 2.17$ and free fat-mass index (FFMI) 20.1.06 \pm 2.12 . From the above values; there was no warning of risk to hypokinetic health problems. No significant differences among final year male and female students in the sports science and coaching department in terms of all the variables, except for waist-to-hip ratio (WHR), fat-free mass (FFM) and fat-mass index (FMI). In regard to somatotype, the mean for male students was 1.60-0.95-0.88 (endomorphic mesomorph) and for female students was 2.02-1.28-0.90 (mesomorphic endomorph).

Conclusion: Body composition depends much on students' weight. It was established that the female students' fat tissue percentage was relatively high in comparison to their male counterparts. Differences in endomorphy and body composition indices had been observed. Physical activity against the students' nutritional habits, training and exercises and age are vital to parameters of body composition.
\end{abstract}

Keywords: anthropometry. body composition, somatotype, endomorphy, mesomorphy, ectomorphy
Volume 8 Issue 3 - 2018

\author{
Adiele Dube,' Patrick Morgan Gundani² \\ 'Department of Health Education, Southern Africa Nazarene \\ University, Swaziland \\ 2Department of Sports Science and Coaching, National \\ University of Science and Technology, Zimbabwe
}

Correspondence: Adiele Dube, Department of Health Education, Southern Africa Nazarene University, Swaziland, Email adieledube@yahoo.com

Received: April 13,2018| Published: June 04, 2018

\section{Introduction}

Anthropometric dimensions, body composition, and morphological characteristics have been known to lay fundamental role in success determination of an athlete's potential. To achieve excellence in specific sports, accurate evaluation of the above characteristics chiefly reflect different proportions required on the quantification of the body's structural components. ${ }^{1-3}$ Physical characteristics such as the anthropometric profiles and somatotype profiles indicate the suitability of sportsperson's potential participate at peak level in sport. ${ }^{4,5}$ An increased interest in anthropometric characteristics, body composition and Somatotype in various competitive sports has been witnessed over the last decades. This allows quantification of the key structural mechanisms of the body; muscle, bone and fat. ${ }^{6,7}$

From over a decade research showed a strong relationship existing between structure and performance ${ }^{8-11}$ anthropometric measurements and body composition at universities ${ }^{12,13}$ Today's world had greatly changed in the $21^{\text {st }}$ century; the practicality of Sport Science in Zimbabwe is still at its infancy. The success of Zimbabweans globally calls for the scientific study of the uniqueness of the athletes. Zimbabwean university students who have experience and different levels 70 of sport codes qualification is scant. Therefore this study aimed describing data on anthropometric measurements, body composition and somatotyping of university sports science and coaching part-time male and female students.

\section{Methodology}

\section{Design}

This was a retrospective, observational, descriptive study. The following variables were analysed: anthropometric measurements consisted of height, weight, 8 skinfolds (triceps, subscapular, biceps, iliac crest, supraspinale, abdominal, front thigh and medial calf), 5 girths (arm relaxed, arm flexed and tensed, waist, gluteal, medial calf circumferences), and 2 bone breadths (humerus and femur).

\section{Sample}

In a class of 46 students, anthropometric data were collected from a sample of 20 Zimbabwean university part time students; 10 male and 10 female respectively. The age of the students was $38.5 \pm 12.5$ years. 
Students' data were collected during the final semester at National University of Science and Technology, in May 2014. The participants studied were physical education teachers with Diploma in Education and holders of national/international coaching certificates in at least one of the 10 sporting disciplines; athletics, basketball, chess, cricket, karate, netball, soccer, swimming, tennis and volleyball. The data were collected only from part-time Class of 2011 Intake 1.

\section{Ethical consideration}

Permission to conduct the study using students as subjects were obtained from the National University of Science and Technology (NUST), Sports science and coaching department. Before data collection, the participants were briefed on the purpose of the study, requirements and demands on them when they participate. Participation was voluntary and subjects could decide not to participate. A verbal consent was obtained from every subject before participation.

\section{Instruments and procedures}

The International Society for the Advancement of Kinanthropometry (ISAK 2011) protocols was followed for each assessment. ${ }^{14}$

\section{Below instruments were used:}

a. Seca 220R telescopic stadiometer (measuring range: $85-200 \mathrm{~cm}$; precision: $1 \mathrm{~mm}$.)

b. Seca $710 \mathrm{R}$ weighing scale, calibrated beforehand (capacity: 200kg; precision: 50g.)

c. Anthropometric tape (precision: $1 \mathrm{~mm}$.)

d. Cescorf Caliper (measuring range: 0-250mm; 116 precision: $1 \mathrm{~mm}$.)

e. Harpenden Caliper skinfold caliper (measuring range: $0-48 \mathrm{~mm}$; precision: $0.2 \mathrm{~mm}$; constant pressure of $10 \mathrm{~g} / \mathrm{mm}^{2}$.)

f. Anthropometer (precision: $1 \mathrm{~mm}$.)

g. Additional equipment (a wax pencil for marking the individual, chalk dust.)

The components were completed 162 as follows:

$$
\text { Endomorphy }=-0.7182+0.1451 \times \Sigma S F-0.00068 \times \Sigma S F^{2}+0.0000014 \times \Sigma S F^{3},
$$

where: $\Sigma \mathrm{SF}=$ sum of skinfolds (triceps + subscapular + supraspinale).

Correct for height by ${ }^{15} \Sigma 3 S F \times 170.18 \div H t($ in $\mathrm{cm})$

Mesomorphy $=0.858 \times$ Humerus breadth $+0.188 \times$ Corrected Arm girth $+0.161 \times$ Corrected Calf girth - Height $\times 0.131+4.5$.

Ectomorphy $=$ Height - Weight ratio $($ HWR) according to the following conditions:

a. If $H W R \geq 40.75$, then: Ectomorphy $=H W R \times 0.732-28.58$

b. If $\mathrm{HWR}<40.75$ but $>38.25$, then: Ectomorphy $=\mathrm{HWR} \times 0.463-$ 17.63

c. If $H W R \leq 38.25$, then: then: Ectomorphy $=0.1$

\section{Statistical analysis}

Mean and standard deviation were calculated and presented $(\mathrm{M} \pm \mathrm{SD})$. Statistical Package in Social Sciences (SPSS) version 20

\section{Anthropometry}

Norton and Olds ${ }^{15}$ anthropometric variables and techniques were used. These variables were measured following the International Society of the Advancement of Kinanthropometry (ISAK 2011) protocol.

\section{Derived variables}

I. For body composition the following variables were computed:

II. Body mass index $(\mathrm{BMI})=$ Body Mass $(\mathrm{BM}) /$ height $^{2}$

III. Fat mass=body weight $(\mathrm{kg}) \times$ percentage body fat $/ 100$

IV. Fat-free mass=body weight $(\mathrm{kg})$-fat mass $(\mathrm{kg})$

V. Fat mass index (FMI) and fat-free mass index (FFMI) were calculated by dividing the fat mass and the fat-free mass by the stature-squared:

VI. Fat mass index $=F M /$ height $^{2}$

VII. Fat-free mass index $=$ FFM/height ${ }^{2}$

VIII. Body density (BD) and Percent body fat (\%BF) from body density were calculated using ${ }^{16}$ equations respectively.

IX. $\mathrm{BD}=1.0988-0.0004(\mathrm{X} 1)$

$$
\% B F=(4.570 / B D-4.142) X 100
$$

where: $\quad X_{1}=\Sigma 7$ skinfolds in $\mathrm{mm}$ (triceps + subscapular+biceps + supraspinale + abdominal + front thigh + medial calf)

The Brozek and Keys ${ }^{16}$ equation was used in calculating \% BF using the values derived for body density.

where BD is body density.

Sheldon's somatotype classification was useful in finding out the subjects' Somatotype characteristics. ${ }^{17}$ The major three components of somatotype were computed using the equations for a decimalised anthropometric somatotype. was used to compute descriptive data. Independent samples t-test was used to test if population means estimated by two independent samples differed significantly. Testing of the differences across sport specialty modules was performed 185 through a one way one-way analysis of variance (ANOVA). Statistical significance was set at probability level of $\leq 0.05$. Somatotype and somatoplots were computed using the Heath-Carter's ${ }^{18}$ method, while Somatotype Analysis of Variance (SANOVA) was calculated using the somatotype software Somatotype 1.1 software based on equations by Carter and Heath. ${ }^{17}$ Somatoplots and somatotype category charts showing all the profiles from each of the 10 gender based sports were presented. Category charts for each of the gender based sports for 13 somatotype categories were plotted showing the percentage profiles (Table 1). 
Table 1 Intake I Block release students body composition descriptive data and ANOVA for females and males ( $\mathrm{n}=20)$

\begin{tabular}{llllll}
\hline & $\begin{array}{l}\text { All } \\
\mathbf{N}=\mathbf{2 0}\end{array}$ & $\begin{array}{l}\text { Females } \\
\mathbf{N = 1 0}\end{array}$ & $\begin{array}{l}\text { Males } \\
\mathbf{N}=\mathbf{1 0}\end{array}$ & & ANOVA \\
\hline Variable & Mean \pm SD & Mean \pm SD & Mean \pm SD & P value & Significance \\
\hline Age (yrs) & $38.5 \pm 12.5$ & $38.5 \pm 12.5$ & $38.5 \pm 7.5$ & 0.203 & NS \\
Mass(kg) & $71.47 \pm 13.23$ & $66.43 \pm 9.39$ & $76.52 \pm 14.99$ & 0.088 & NS \\
Height(m) & $1.68 \pm 0.07$ & $1.65 \pm 0.07$ & $1.70 \pm 0.06$ & 0.102 & NS \\
BMI & $25.07 \pm 3.18$ & $24.18 \pm 2.66$ & $25.96 \pm 3.54$ & 0.22 & NS \\
$\%$ BF & $10.6 \pm 0.14$ & $10.5 \pm 0.05$ & $10.6 \pm 0.13$ & 0.100 & NS \\
$\sum 8 S K F$ & $116.24 \pm 52.53$ & $133.24 \pm 55.04$ & $99.23 \pm 46.41$ & 0.152 & NS \\
WHR & $0.81 \pm 0.09$ & $0.74 \pm 0.05$ & $0.89 \pm 003$ & $0.000^{*}$ & $\mathrm{~s}$ \\
FM (kg) & $13.7 \pm 6.35$ & $14.4 \pm 6.15$ & $13.0 \pm 6.80$ & 0.651 & NS \\
FFM (kg) & $57.73 \pm 9.97$ & $52.02 \pm 6.09$ & $63.44 \pm 10.01$ & $0.006^{*}$ & $\mathrm{~s}$ \\
FM1 & $4.81 \pm 2.17$ & $5.25 \pm 2.26$ & $4.38 \pm 2.10$ & 0.385 & NS \\
FFMI & $201.06 \pm 2.12$ & $18.92 \pm 1.06$ & $21.58 \pm 2.12$ & $0.002^{*}$ & $\mathrm{~s}$
\end{tabular}

Db, body density; BMI, body mass index; WHR, waist-hip-rntio; 2:8SJF, smn of skinfolds; \%BF, percentage body fat; FM, fat mass; FFM, fat free mass; FMI, fat mass index; FFMI, fat free mass index.

\section{Results}

\section{Body composition measurements}

Sports science students indicated significance relationship $(0.000)$ based on gender based waist hip ratio, fat-free mass (0.006) and fat-free mass index (0.002). However, there was a slightly higher adiposity of $10.6 \%$ as their average percent body fat $(\% \mathrm{BF})$

\section{Somatotype variables}

Table 2 below presents somatotype and body composition of the subjects. Although Carter \& Heath ${ }^{18}$ defined the 13 categories; the present study showed that all the university students who participated

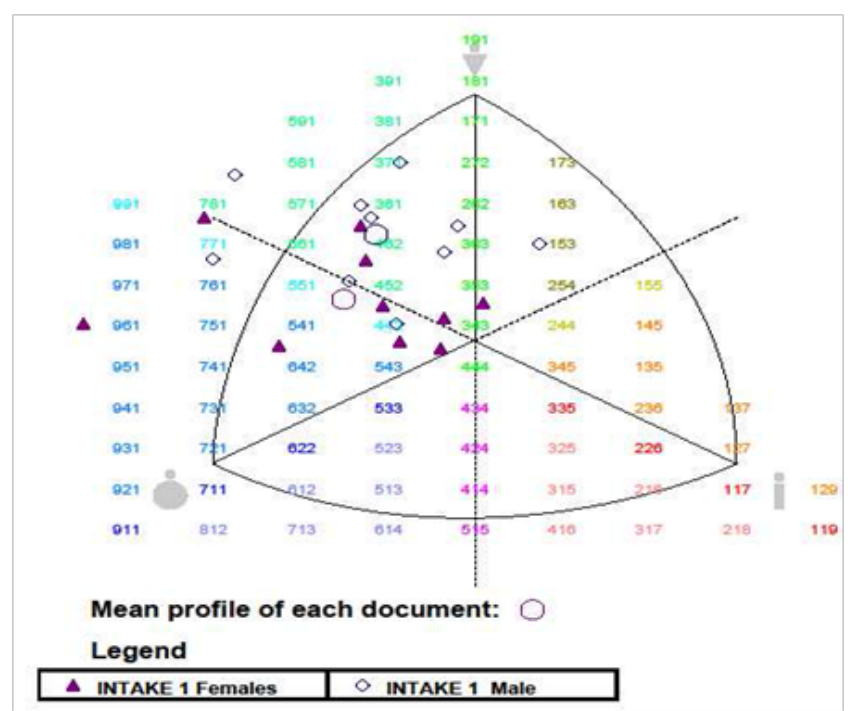

Figure 1 Distribution of somatoplots for intake 1 block release students $(n=20)$. in this study fell into only 5 categories. The mean somatotype of the male students was 3.53-4.99-1.28 and for female students was 4.53-4.04-1.54 hence the part-time sports science intake was categorised as either endomorphic-mesomorphs or mesomorphic endomorphs; thus muscle-skeletal development succeeds over the other components (adiposity and linearity) (Table 3). There were no significant differences in somatotype between gender groups and speciality module $(p>0.05)$, although male students presented the highest mesomorphy and least ectomorphy. Females had the highest endomorphic component value $(4.53 \pm 2.02)$ (Figure 1) (Figure 2). However, both genders were highly developed in mesomorphic component while endomorphic component was greater compared to ectomorphic component (Table 4).

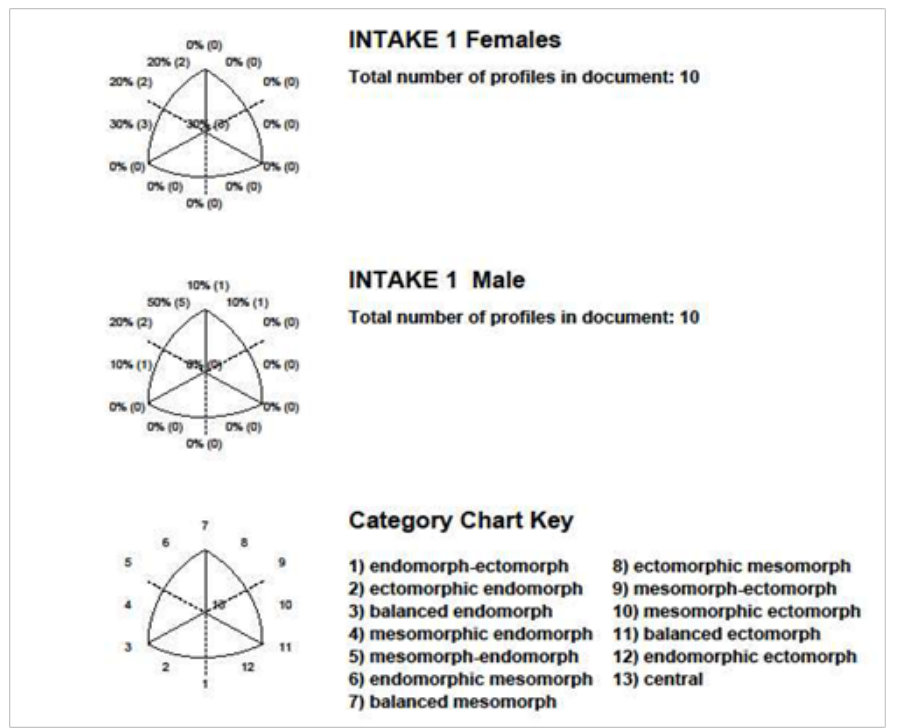

Figure 2 Distribution of somatoplots for intake 1 block release students $(\mathrm{n}=10)$. 
Table 2 Somatotype of students according to gender

\begin{tabular}{lllll}
\hline Variable & \multicolumn{5}{l}{ Somatotype } \\
\hline & Endomorphy & Mesomorphy & Ectomorphy & P-value \\
\hline Males $(\mathrm{n}=10)$ & $3.53 \pm 1.60$ & $4.99 \pm 0.95$ & $1.28 \pm 0.88$ & \\
Females $(\mathrm{n}=10)$ & $4.53 \pm 2.02$ & $4.04 \pm 1.28$ & $1.54 \pm 0.90$ & \\
ALL $(\mathrm{n}=20)$ & $4.03 \pm 1.81$ & $4.52 \pm 1.12$ & $1.41 \pm 0.89$ & 0.056
\end{tabular}

Table 3 Somatotype Analysis of Variance (ANOVA) $(n=20)$

\begin{tabular}{llll}
\hline Group & Count & Mean & SD \\
\hline Females & 10 & $4.53-4.04-1.54$ & $2.02-1.28-0.90$ \\
Males & 10 & $3.53-4.99-1.28$ & $1.60-0.95-0.88$ \\
ANOVA & $\mathrm{F}=1.83$ & $\mathrm{p}=0.19$ & \\
\hline
\end{tabular}

Table 4 Selected Studies of national athletes/ students from the literature

\begin{tabular}{|c|c|c|c|c|c|}
\hline Author & Mass (Kg) & Height(m) & $\% \mathbf{B F}$ & BMI & Somatotype \\
\hline Salgado et al. 2008 & $70.5 \pm 7.9$ & $1.75 \pm 0.06$ & $16.1 \pm 4.3$ & - & $3.03-4.78-2.55$ \\
\hline Helgerud et al. 2001 & $72.2 \pm 0.11$ & $\mathrm{I} .8 \mathrm{I} \pm 0.06$ & - & 21.97 & - \\
\hline $\begin{array}{l}\text { Adhikari \& McNeely } \\
2015\end{array}$ & $76.5 \pm 8.0$ & $|78.| \pm 6 . \mid$ & $23.4 \pm 2.9$ & - & 3.I-4. I-2.3* \\
\hline \multirow[t]{2}{*}{ Present Study } & $71.47 \pm 13.23$ & $1.71 \pm 0.07$ & $10.5 \pm 0.14$ & $25.07 \pm 3.18$ & M 3.53-4.99-1.28 \\
\hline & & & & & F 4.53-4.04-I.54* \\
\hline
\end{tabular}

\section{Discussion}

In the present study, anthropometric characteristics of Sports science and coaching part-time students were evaluated according to gender and not as athletes, coaches or non-athletes. All students under study classified as adults. The students were of medium stature; males $1.70 \pm 0.06 \mathrm{~m}$ and their female counterparts $1.65 \pm 0.07 \mathrm{~m}$. Height is critical in an individual's development; hence lays a strong base tin relation to other anthropometric measurements. ${ }^{19}$ Consistency in physical characteristic of the students showed the trend of specific sporting they majored in. Similar findings were reported by Mayhew et al. ${ }^{20}$

The university students showed BMI values for female as $24.18 \pm 2.66$ and males $25.96 \pm 3.54$ respectively. There was no significant relationship (0.220) in BMI between female and their male counterparts. The classification of BMI according to the World Health Organization (WHO, 2004), most of the male students are overweight and pre-obese whilst their female counterparts are with normal BMI. Part time sports science students who had BMI above the normal, had muscle mass and not excessive body fat as witnessed (Table 1). ${ }^{21-25}$

The students presented a slightly higher adiposity of $10.6 \%$ as their average percent body fat $(\% \mathrm{BF})$ which though was lower than most of the sports university students. This however was not in accordance to the American Council of Exercise (2009) which indicated that students' body fat ranged from $14-20 \%$ and $18-24 \%$; for males and females respectively which they considered to be medium. The present study was similar to recent studies on for university students which stipulate that students who were athletes had higher BMI and body weight which reflected greater muscle mass than greater adiposity. ${ }^{26-29}$ The average somatotype characteristic of part-time sports science students indicated as mesomorph-endomorph (males 3.53-4.99-1.28; and females 4.53-4.04-1.54). Both females and male students were average in muscularity and only a quarter of the group from both gender had ectomorphic component. The results were different from the other researches carried out elsewhere. Therefore, Zimbabwean students are muscular but lean despite having average endomorphic components. ${ }^{30-32}$

\section{Conclusion}

The results of Zimbabwean university students showed no much difference in body weight, anthropometric measurements and body composition. Using applied science, sport scientists provide answers to questions often asked by coaches and technical personnel in such areas like talent identification, physical fitness monitoring, team selection and training methods. Periodic completion of precise and correct evaluations of body composition relative to the training period and intensity provide enhanced chances to assess current status and training adaptability of an athlete.

\section{Limitations of the study}

The subjects involved were the first intake for the block-release programme. These were a working class, who were working in schools with teaching experience stretching more than three years. The program was still at its infancy, hence was mostly marketed to manpower in the education sector.

\section{Acknowledgements}

The Department of Sports science and coaching.

\section{Conflicts of interest}

No conflict of interests is declared. 


\section{References}

1. Dunford M, Doyle JA. Nutrition for Sport \& Exercise, 4th Ed. United States of America. Cengage Publishers; 2017.

2. Sinning WE, Wilson JR. Validity of generalized equations body composition analysis in women athletes. Research Quarterly for exercise and Sport. 1996;55:153-160.

3. Amit Bandyopadhyay. Anthropometry and Body Composition in Soccer and Volleyball Players in West Bengal, India. J Physiol Anthropology. 2007;26(4)501-505.

4. Fox Edward L, Donald K Mathew. The Physiological Basis of Physical Education and Athletics. 3rd ed. Philadelphia; CBS College, Publishing; 1981.

5. Makaza D, Amusa LO, Goon DT, Gundani MP, Mugandani SC, Toriola AL. Body composition and somatotype of male Zimbabwean league basketball players. African Journal for Physical, Health Education, Recreation and Dance (AJPHERD). 2011;17 (1):81-95.

6. McArdle WD, Katch FI, Katch VL. Exercise Physiology. 4th ed. Baltimore: Williams and Wilkins; 1996.

7. McArdle WD, Katch FI, Katch VL. Exercise Physiology. 7th ed Baltimore: Williams and Wilkins; 2010.

8. Guennadi G. Anthropometric and physical fitness parameters for high jumpers of different age groups. Scientific journal. 1990;13:9-10.

9. Rienzi E, Drust B, Reilly T, Carter JE, Martin A. Investigation of anthropometric and work rate profile of elite South American international soccer players. J Sport Med Phy Fit. 2000;40:162-169.

10. Gualdi RE, Zaccagni L. Somatotype, role and performance in elite volleyball players. J Sports Med Phys Fitness. 2001;41:256-262.

11. Pelin C, Kurkuoglu A, Ozener B, \& Yazici AC. Anthropometric characteristics of young Turkish male athletes. Colligium Anthropol. 2009;33:1057-1063.

12. Ismail MN, Chi CB. Energy balance study in obese students. Proc Nutr Soc Mal. 1987;2:4350.

13. Ismail MN. Energy requirements of Malaysian students. Proc Nutr Soc Mal. 1988;3:63-72.

14. ISAK, International Standards for Anthropometric Assessment. ISAK manual International Society for the Advancement of Kinanthropometry (ISAK). Lower Hutt, New Zealand; 2011.

15. Norton K, Marfell-Jones M, Whittingham N, Carter L, Kerr D. Anthropometric assessment protocols. In: Gore CJ, editor. Physiological tests for elite athletes. Champaign: Human Kinetics. 2000;1:66-85.

16. Brozek J, Grande F, Anderson JT \& Keys K. Densitometric analysis of body composition: Revision of some quantitative assumptions. Ann NY Acad Sci. 1963;110:113-140.

17. Heath B, Carter J. A modified somatotype method. Am J Physiol Anthrop. 1967;27:57-74.

18. Carter JEL, Heath BH. Somatotyping-Development and Applications. Cambridge: Cambridge University Press; 1990.

19. Corbin CB, Lindsay R. Higher Concept of Physical fitness. United States of America; Time Mirror Education Group Inc; 1997.

20. Mayhew JL, Piper FC, Holmes JA. Prediction of body density, fat weight and lean body mass in male athletes. $J$ Sports Med. 1981;21:383-389.

21. Carter JEL. Somatotypes of Olympic athletes. Physical Structure of Olympic Athletes. Part II: Kinanthropometry of Olympic Athletes. Karger, Basel. 1984;16:80-109.

22. Faulkner JA. Physiology of swimming and diving. Falls H, editor Exercise Physiology. Academic Press, Baltimore; 1968.

23. Gutin BA. Model of Physical Fitness and dynamic health. Journal of Physical Education \& Recreation. 1980;14:49-55.

24. Matthew DK. Measurement in Physical Education. 2nd Ed. Philadelphia W.B. Saunders; 1980.

25. Meltzer A, Mueller W, Annegers J, Grimes B and Albright D. Weight history and hypertension. J Clin Epidemiology. 1988;41:867-874.

26. Morrow JR, Disch JC, Ward PE, Donavan TJ, Katch VL. Anthropometric Strength and performance characteristics of American world class thrower. J Sport med Phy Fit. 1982;22:73-79.

27. Tanner JM. The physique of the Olympic athletes. London, George Allen \& Unwin; 1964.

28. Thomas Battinelli. Physique, fitness, and performance. CRC Press 2000 .

29. Ramana V, Kumari S, Rao S \& Balakrishna S. Effect of changes in body composition profile on $\mathrm{VO}_{2}$ max and maximal work performance in athletes. Journal of Exercise Physiology. 2004;7(1):34-39.

30. Underlay C, De Ridder JH, Amusa LO, Toriola AL \& Adeogun O Physique characteristics of world-class African long distance runners. African Journal for Physical, Health Education, Recreation and Dance. 2005;11(1):6-16

31. Lohman TG, Houtkooper L, Going SB. Body fat measurement goes hightech: not all are created equal. ACSMS Health Fit J. 1997;1(1):30-35.

32. Liliana-Elisabeta Radua, Fatih Hazarb, Alexandru-Rares Punic Anthropometric and Physical Fitness Characteristics of University Students Procedia-Social and Behavioral Sciences. 2014;149:798-802. 